\title{
LA EFICIENCIA: ENTRE LA REALIDAD Y LA FICCIÓN
}

\author{
VIVIANA H. PEÑA
}

- Profesora de Fundamentos de la Gerencia

Área Académica de Administración

Facultad de Negocios, UPC

La eficiencia en la gestión organizacional ha sido el constructo más estudiado de la administración. Su popularidad se sustenta en algo más que una coincidencia dejada al azar; se remonta a los orígenes mismos de la era industrial a finales del siglo XVIII, cuando los nuevos empresarios mercantilistas propugnaban por construir economías de escala que permitieran la subsistencia del negocio y el cambio en los modelos de producción industrial. De esos tiempos devinieron los de la era informática y la de las telecomunicaciones, bajo cuyo predominio siguieron las tendencias a inversiones cuantiosas de grandes grupos económicos, las más de las veces, oligopólicos.

\section{...LA COMPETENCIA ENARDECIDA; LA POCA LEALTAD DE LOS USUARIOS; Y LA APERTURA A LOS MERCADOS GLOBALES SON LAS CAUSAS PRINCIPALES QUE OBLIGAN ACTUALMENTE A MANTENER NIVELES DE EFICIENCIA POR UNIDAD DE MEDIDA...}

Las investigaciones actuales señalan que la competencia enardecida; la poca lealtad de los usuarios; y la apertura a los mercados globales son las causas principales que obligan actualmente a mantener niveles de eficiencia por unidad de medida, desde fracciones de segundo hasta de centavo. La lucha se ha trasladado de las industrias a los servicios más sofisticados y con atractivos márgenes de utilidad; así como de los productos a los bienes y/o servicios intangibles, capaces de generar valor en un mercado de expectativas, sorpresas, novedades y obsolescencias permanentes.

Surgen como interrogantes cuáles son los paradigmas de la eficiencia hoy y si es posible la calidad. Lejos quedaron los tiempos en que solo importaban cuantiosos volúmenes o márgenes; a estos se le añaden los esfuerzos comerciales y las batallas en el punto de venta y la postventa así como la gestión a lo largo de la cadena de valor. Las marcas han tomado un papel preponderante en la batalla por cada centavo, detrás de las cuales hay un costoso y delicado modelo cuidadosamente hilvanado. En ese complejo tejido de filigrana se asienta la calidad, quizá el constructo más etéreo, esquivo y personal cuando de investigación académica se trata.

El consumidor es exigente y como "amante", es tan leal como un mozo adolescente en pleno apogeo y efervescencia hormonales; mira, compara y experimenta ante lo nuevo delante de sus ojos. Las posibilidades de personalización de los productos y servicios le dan la ilusión de que es posible satisfacer todas sus demandas. El límite de la eficiencia pareciera hallarse en los costos incurridos para hacer posible esta adecuación a una mayoría de los usuarios potenciales.

La eficiencia encuentra su contrapeso en la eficacia y en la necesidad de sostenibilidad. La diada "eficacia-eficiencia" es por tanto la ecuación simbólica que si bien es cierto restringe los avances y ambiciones, permite también un progreso armónico en tanto el deseo al encuentro de la realidad se establece en el límite de lo posible, a decir de otra forma, lo que vale la pena; el esfuerzo en tanto satisface una necesidad verdadera y de una manera adecuada y suficiente.

La perentoriedad manifiesta en la impaciencia e incapacidad de postergación hace del consumidor un espectador ávido donde la inmediatez articulada por la virtualidad da la falsa ilusión de un acceso irrestricto a cualquier suministro. El surgimiento de los sistemas de control y monitoreo; como los de la gestión en la cadena de suministro y los sistemas de distribución en sus diferentes modalidades dan forma a esta realidad que hace posible contar con soluciones y respuestas al toque de una pantalla. Aún así, la calidad no está garantizada ante los ojos de los usuarios para quienes estos afanes pueden pasar desapercibidos.

\footnotetext{
LA DIADA "EFICACIA-EFICIENCIA" ES POR TANTO LA ECUACIÓN SIMBÓLICA QUE SI BIEN ES CIERTO RESTRINGE LOS AVANCES Y AMBICIONES, PERMITE TAMBIÉN UN PROGRESO ARMÓNICO...
} 
En un lado de la pantalla está un consumidor ansioso y en el otro, un oferente dispuesto a hacer realidad sus deseos a cambio de pago. Es en la negociación que la realidad se enfrenta con la fantasía. El tiempo y el espacio median para dibujar el terreno de lo posible. La insatisfacción permanente es el sino de la búsqueda humana y el motor que incentiva a crear, construir y hacer posible sus anhelos y proyectos. Cuando estos afanes se ven reflejados en un producto cuyas expectativas son superadas y el consumidor se eclipsa, da la impresión de haberse tocado la calidad.

En los intercambios voluntarios se establecen los términos en los que ambas partes pueden satisfacer parcialmente sus requerimientos con algún sacrificio y en donde se procurará propiciar una vinculación que trascienda lo fútil o lo esporádico. Los costos de cada uno de estos intentos son altos y exigen de modelos integrales de asignación, mantenimiento y reformulación de la dinámica del entorno. Más allá de los cambios, es en las limitaciones humanas para lidiar con la complejidad en las que descansan las posibilidades reales.

La experiencia ha demostrado además que la eficiencia en exceso atenta contra la calidad y la eficacia en el mediano plazo. La eficiencia y la calidad son tan sólidas como escurridizas de aprehender y en tanto una se aproxima a la otra, su propia naturaleza las obliga a alejarse. Sostengo que sin la necesaria ambivalencia generada por este encuentro sería imposible el impulso generador de cambios o el espíritu emprendedor. 